\title{
LODZ RADIOCARBON DATES I
}

\author{
ANDRZEJ KANWISZER and PAWEL TRZECIAK \\ Archaeological and Ethnographical Museum in Lódź \\ 91-415 Lódź, pl Wolności 14, Poland
}

The Radiocarbon Laboratory of the Archaeological and Ethnographical Museum in Lódź was established to meet the growing demand for radiocarbon dating of archaeologic and geologic samples. The liquid scintillation technique based on the Polish liquid scintillation counter with a single photomultiplier began operation in 1966. The base for the measurements was ethylbenzene. In 1974 new facilities for the determination of radiocarbon assays were installed. The proportional counter and the electronics supplied by Nuclear Enterprises became routine counting, equipment two years later.

Measurements are performed with the help of a ca $2 \mathbf{L}$ effective volume proportional counter with methane as the operating gas. The main detector is surrounded by a $10 \mathrm{~L}$ dead methane flow counter which forms the anticoincidence system. The counter system is totally covered with a massive 25 to $30 \mathrm{~cm}$ iron shield, 10 to $15 \mathrm{~cm}$ block of borax/polyester resin, and an extra $5 \mathrm{~cm}$ layer of old lead. At a working pressure of methane equal to 1000 torr, the background and net contemporary values $(95 \%$ of NBS oxalic acid) are, respectively, $4.26 \pm 0.04$ and $19.60 \pm$ $0.20 \mathrm{cpm}$. Every sample is measured 80 times for 60 minutes. The NBS oxalic acid standard and background are counted once a month. Dates are expressed in years BP. Age calculations are based on the 5570-year Libby ${ }^{14} \mathrm{C}$ half-life and on a contemporary value equal to 0.95 of the activity of the NBS oxalic acid standard. Deviations reported are based on counting statistics of sample, background, and modern, and are $\pm 1 \sigma$, except that when sample count approaches either modern or background, $2 \sigma$ limits are reported. The results are not corrected for the ${ }^{13} \mathrm{C}$ fractionation.

The method applied for methane conversion is based on the modified technique of organic combustion analysis. Samples are combusted in a quartz tube in a stream of purified oxygen (Libby, 1952) or by the combustion bomb method (Barker, Burleigh, and Meeks, 1969; Switsur, Hall, and West, 1970; Switsur, 1974) followed by trapping and purification of the $\mathrm{CO}_{2}$ and subsequent conversion to $\mathrm{CH}_{4}$ by hydrogenation via Ru catalyst (Fairhall, Schell, and Takashima, 1961). All methane samples are stored for one month in stainless steel containers to permit radon decay. The basic pretreatment of samples which are generally wood, peat, or charcoal, consists of visual examination for intrusive rootlets followed by boiling in $2 \% \mathrm{HCl}, 2 \% \mathrm{NaOH}$, and $2 \% \mathrm{HCl}$, successively (Bern et al, 1978). Between each treatment the sample is washed in boiling distilled water and finally is kiln-dried at $100^{\circ} \mathrm{C}$ in a vacuum.

\section{ACKNOWLEDGMENTS}

We would like to express our gratitude to J Kroh, Director, Radiation Technique Institute, Lódź Technical University, for his scientific 
support. We also acknowledge B Zaborski of Canada for his kind service of dispatching the complete set of RADIOCARBON to us for the past 14 years.

\section{SAMPLE DESCRIPTIONS}

\section{ARCHAEOLOGIC SAMPLES}

\section{Radziejów Kujawski series}

Charred grains from Radziejów Kujawski $\left(52^{\circ} 35^{\prime} \mathrm{N}, 18^{\circ} 30^{\prime} \mathrm{E}\right)$ and Opatowice $\left(52^{\circ} 50^{\prime} \mathrm{N}, 18^{\circ} 50^{\prime} \mathrm{E}\right)$, Włocławek prov, extremely rare discovery in area of TRB culture. Thirty pits excavated in area $325 \mathrm{~m}^{2}$. Largest pits were 1.8 to $2 \mathrm{~m}$ diam; 2 pits contained several $\mathrm{kg}$ of charred wheat. One pit situated at Radziejów Kujawski (Gabałówna, 1970; Grygiel, 1977). Another pit was discovered at Opatowice on Site 12, in $\mathrm{NE}$ part of rise partly destroyed by gravel quarry. At Opatowice charred wheat lay in shallow pit in TRB settlement at depth 1.15 to $1.3 \mathrm{~m}$ below ground surface. Paleobotanic analysis of grain was made by M Klichowska, Paleobot Centre, Inst Hist Material Culture, Polish Acad Sci, Poznań. First sample coll and subm by L Gabałówna, Archaeol and Ethnog Mus, Lódź. Second sample coll and subm by R Grygiel, Archaeol and Ethnog Mus, Lódź.

\section{LOD-1. Radziejów Kujawski}

$4670 \pm 380$

Charred wheat.

\section{LOD-20. Opatowice}

$4320 \pm 180$

Charred grains, depth $1.1 \mathrm{~m}$.

General Comment: charred wheat from Opatowice and Radziejów Kujawski should be interpreted as sacrificial offerings made during ritual practices.

\section{LOD-2. Kozienice}

$150 \pm 45$

Wood, remains of bridge from Kozienice $\left(51^{\circ} 50^{\prime} \mathrm{N}, 21^{\circ} 30^{\prime} \mathrm{E}\right)$, Radom prov. Coll and subm by A Kanwiszer.

General Comment: bridge built by Napoleon's soldiers in 1812 (check sample).

\section{Leczyea series}

Three samples of oak from Lęczyca and Tum $\left(52^{\circ} 10^{\prime} \mathrm{N}, 19^{\circ} 20^{\prime} \mathrm{E}\right)$, Płock prov. Samples date from medieval fortress town complex near Lęczyca, established on main crossroad of central Poland (Warsaw-Berlin ice-marginal valley and Bzura valley). Settlement controlled passage through Bzura R. Coll and subm by T Poklewski, Inst Material Culture Hist, Polish Acad Sci, Lódź.

LOD-3. Leczyca

$1860 \pm 120$

Oak fragments of well boarding, surfical part of trunk. Well was on grounds of coal mine in Lęczyca. 
LOD-6. Tum 1

$1740 \pm 120$

Oak, surfical part of trunk from timber fortification.

LOD-7. Tum 2

$1710 \pm 120$

Oak trunk, $0.25 \mathrm{~m}$ thick, surfical part.

\section{Przywóz series}

Charcoal from Przywóz $\left(50^{\circ} 05^{\prime} \mathrm{N}, 18^{\circ} 40^{\prime} \mathrm{E}\right)$, Sieradz prov. Some $400 \mathrm{~km} \mathrm{~N}$ of ancient Roman frontier towns there was, in 2nd and 9rd centuries AD, a small settlement and two assoc barrows, on upper Warta, tributary of Odra R, in area called "Barbaricum". Studies were made in village of Przywóz which lies on border of two historical provs, Great Poland and Silesia. Village is in S part of central Poland, on left bank of Warta $R$. The only commodity valued during Roman period until Late Middle ages was iron ore available over large subsurface area, mined for several centuries.

General Comment: two methods were used for dating settlement at Przywóz-classic archaeol method based on comparison of uncovered material such as terra sigilata, local pottery, coins and fibulae, and ${ }^{14} \mathrm{C}$ analysis. On archaeol grounds, beginning of settlement was assigned to 2nd half of 2 nd century AD, and its end to lst half of 4 th century AD.

Coll and subm by K Jazdzewski, Archaeol and Ethnog Mus, Lódź.

LOD-4. Przywóz 1

$1670 \pm 90$

Charcoal.

LOD-64. Przywóz 2

$1690 \pm 110$

Charcoal, Sec XLIX, Pit 207.

LOD-65. Przywóz 3

$1720 \pm 110$

Charcoal, Sec XLIII, Site 1a, hearth of 2nd cottage.

LOD-66. Przywóz 4

$1800 \pm 100$

Charcoal, Sec XXXIX in ditch, ca $160 \mathrm{~m}$ from $\mathrm{N}$ wall at $\mathrm{W}$ wall.

LOD-67. Przywóz 5

$1750 \pm 120$

Charcoal, Sec XIIII, hearth of 2nd cottage.

LOD-68. Przywóz 6

$1780 \pm 100$

Charcoal, Sec XLIV, Trench 44, Cottage 3, Pit 226.

LOD-69. Przywóz 7

$5490 \pm 140$

Charcoal, Sec L, Pit 218, depth 0.5 to $0.6 \mathrm{~m}$.

LOD-75. Przywóz 8

$1760 \pm 100$

Charcoal, Sec XLIII, Trench 43 and 44 (subterranean hut), from hearth overlying ash.

LOD-76. Przywóz 9

$1860 \pm 110$

Charcoal, Sec XLIII, hearth of 2nd cottage. 
LOD-79. Przywóz 10

Charcoal, Sec LI, Trench 47.

LOD-80. Przywóz 11

$1640 \pm 120$

Charcoal, Sec LI, Trench 48.

LOD-5. Kałdus

$830 \pm 80$

Charred wood from Kałdus $\left(52^{\circ} 25^{\prime} \mathrm{N}, 18^{\circ} 35^{\prime} \mathrm{E}\right)$, Toruń prov. Sample coll from multicomponent settlement. Coll and subm by J Janikowski, Dist Mus, Torun.

\section{Rekoraj series}

Excavations were made in single-enclosure ring earthwork at Rękoraj $\left(51^{\circ} 30^{\prime} \mathrm{N}, 19^{\circ} 40^{\prime} \mathrm{E}\right)$, Piotrków Trybunalski prov. Study of Site 1 was conducted in 1967-69 and 1971. Site lies on right bank of Moszczanka R in watershed of Pilica $\mathrm{R}$ on promontory of sandy rise which gently descends into marshy valley of Moszczanka R. Timber-earth rampart was raised on slope of promontory. ${ }^{14} \mathrm{C}$ dates were measured on charred timber from main rampart. Samples coll and subm by A Chmielowska, Archaeol and Ethnog Mus, Lódź.

\section{LOD.9. Rekoraj 1}

Charcoal, depth $0.5 \mathrm{~m}$.

LOD-51. Rekoraj 2

$$
920 \pm 100
$$

Charcoal, Unit 1 , Sec 3, depth $0.9 \mathrm{~m}$.

LOD-52. Rekoraj 3

$$
840 \pm 120
$$

Charcoal, Unit 1, Sec 3, N part of Rampart I. Depth $0.9 \mathrm{~m}$.

LOD-54. Rekoraj 4

$860 \pm 120$

Charcoal, Unit 1, Sec 3, depth $0.9 \mathrm{~m}$.

LOD-55. Rekoraj 5

$730 \pm 120$

Charcoal, carbonized wood of construction, Unit 1, Sec 3, depth $0.9 \mathrm{~m}$.

LOD-56. Rekoraj 6

$900 \pm 110$ Sec 4 .

Charcoal under clay floor taken for paleomagnetic study. Unit 1,

LOD-57. Rekoraj 7

$770 \pm 110$

Charcoal, Unit 1, Sec 3, Quarter B, depth 0.6 to $0.7 \mathrm{~m}$.

LOD-58. Rekoraj 8

$760 \pm 110$

Charcoal, Unit 1, Sec 4, depth $0.1 \mathrm{~m}$.

LOD-59. Rekoraj 9

$840 \pm 110$

Charcoal, Unit 1 , Sec 3 , depth $0.08 \mathrm{~m}$. 


\section{Parleza Mała series}

Two samples of charcoal from Parleza Mała $\left(53^{\circ} 51^{\prime} \mathrm{N}, 21^{\circ} 03^{\prime} \mathrm{E}\right)$, Olsztyn prov. Coll and subm by K Nowak, Inst Archaeol, Warsaw Univ.

LOD-38. Parleza Mała 1

Charcoal, Unit 1. Sample coll $0.6 \mathrm{~m}$ under humus.

LOD-39. Parleza Mała 2

$6560 \pm 190$

Charcoal, Unit 1 , Pit 5 , depth 0.5 to $0.7 \mathrm{~m}$ below top of pit.

\section{Zawada series}

Charcoal from Zawada village $\left(50^{\circ} 28^{\prime} \mathrm{N}, 21^{\circ} 20^{\prime} \mathrm{E}\right)$, Tarnobrzeg prov. Samples coll from small elev on meadow near Zawada. Dated to determine decline of Lusatian culture in area. Coll and subm by J Michalski, Inst Archaeol, Warsaw Univ.

LOD-42. Zawada 1

$2390 \pm 110$

Charcoal, probably remains of charred pillar beams, Trench 16, E part of excavations, depth 0.9 to $1.1 \mathrm{~m}$.

LOD-45. Zawada 2

$$
2380 \pm 110
$$

Charcoal post hole filling, Trench 16, E part of excavations, depth 0.94 to $1.24 \mathrm{~m}$.

LOD-46. Zawada 3

$2400 \pm 130$

Charcoal filling of Pit 80, Trench 18, NW part of excavations of cultivated field, depth 1 to $1.2 \mathrm{~m}$.

LOD-48. Zawada 4

$2420 \pm 130$

Charcoal, burn layer at bottom of Pit 83, Trench 16, S part of excavations, depth 0.85 to $1 \mathrm{~m}$.

LOD-50. Zawada 5

$2320 \pm 120$

Charcoal, lower part of filling, Pit 70, Trench 17, NW part of excavations on cultivated field, depth 0.5 to $0.9 \mathrm{~m}$.

LOD-53. Zawada 6

$2340 \pm 90$

Charcoal, Pit 72, Trench 15, E part of excavations, depth 0.4 to $0.6 \mathrm{~m}$.

\section{LOD-88. Zawada 7}

$2440 \pm 130$

Charcoal, bottom of Trench 103, W part of rise, at culmination of rise, depth 1.1 to $1.2 \mathrm{~m}$.

\section{LOD-89. Zawada 8}

Charcoal from filling material of Trench 112, NW part of site, on point of rise.

LOD.90. Zawada 9

Charcoal from filling material of S part of Trench 113, NW part of site, on point of rise. 
LOD-49. Iwanie

Charcoal, Komorow culture barrow, Równe dist $\left(50^{\circ} 25^{\prime} \mathrm{N}, 25^{\circ} 40^{\prime}\right.$ E), USSR. Coll and subm by I Swiesznikowa, Lwów.

\section{LOD-60. Wietrzychowice}

Charcoal from Wietrzychowice $\left(52^{\circ} 10^{\prime} \mathrm{N}, 18^{\circ} 55^{\prime} \mathrm{E}\right)$, Konin prov. Sample from Kuyavian barrow cemetery of Funnel Beaker culture from beginning of Period II of Polish Neolithic, 3650-2600 yr Bc. Second tomb. Cemetery is in forest on small flexure of ground, on meadow bog, remains of ancient river. Depth 1.2 to $1.4 \mathrm{~m}$. Coll and subm by K Jazdzewski.

\section{Stryczowice series}

Charcoal from Stryczowice $\left(50^{\circ} 52^{\prime} \mathrm{N}, 21^{\circ} 43^{\prime} \mathrm{E}\right)$, Kielce prov, coll during systematic excavation. Dating results helped solve problem of separating stages of settlement of Funnel Beaker and Lengyel cultures. Samples coll and subm by A Uzarowicz-Chmielewska, Nat Archaeol Mus, Warsaw.

LOD-61. Stryczowice 1

Charcoal, arable field, Trench 1 on plateau, depth 0.7 to $0.8 \mathrm{~m}$.

LOD-62. Stryczowice 2

Charcoal, fragments scattered in trench, on Neolithic deposit. Arable field, Trench 5a on plateau, depth 1 to $1.3 \mathrm{~m}$.

LOD-63. Stryczowice 3

$4360 \pm 210$

Charcoal, fragments scattered in Trench 5b on plateau. Arable field, depth 1.2 to $1.5 \mathrm{~m}$.

\section{Lesno series}

Three samples from Leśno $\left(53^{\circ} 57^{\prime} \mathrm{N}, 17^{\circ} 42^{\prime} \mathrm{E}\right)$, Bydgoszcz prov. First sample coll from skeletal tomb. Two remaining samples come from prince's tomb which dates from Roman period. Coll and subm by A Kanwiszer.

LOD-70. Lesno 1

$$
1920 \pm 110
$$

Moss, skeletal tomb No. 1, Sec 4.

LOD-71. Lesno 2

$$
140 \pm 60
$$

Charcoal, prince's grave. Sample coll from layer under pavement.

\section{LOD-81. Lesno 3}

$130 \pm 60$

Charcoal, prince's grave. Sample coll from external layer of stone pavement, from geometric center of stone circle.

\section{Czerchów series}

Charcoal from Cizerchów ( $\left.51^{\circ} 58^{\prime} \mathrm{N}, 19^{\circ} 43^{\prime} \mathrm{E}\right)$, Lódź prov. Samples come from early Medieval circular earthwork. Dated to establish chronology of earthwork. Coll and subm by A Chmielowska, Archaeol and Ethnog Mus, Lódź. 
LOD-72. Czerchów I

Charcoal, Excavation I, Sec 11, Profile E, suburb, depth $0.4 \mathrm{~m}$.

LOD-73. Czerchów 2

$660 \pm 90$

Charcoal, Excavation I, Sec 11, Layer 2, depth $1.77 \mathrm{~m}$.

LOD-74. Czerchów 3

$650 \pm 90$

Charcoal, Excavation I, Sec 11, NE corner, suburb.

\section{LOD-82. Leg Piekarski}

$1920 \pm 110$

Wood from Leg Piekarski ( $51^{\circ} 55^{\prime} \mathrm{N}, 18^{\circ} 39^{\prime} \mathrm{E}$ ), Konin prov. Sample comes from cemetery which dates from early Roman period. Dated material was taken from outside part of press-boarded floor of grave. Quarter 3 and 4, Grave A. Coll and subm by K Jazdzewski.

LOD-92. Kreta

$9650 \pm 220$

Reindeer antler from Kreta $\left(53^{\circ} 01^{\prime} \mathrm{N}, 22^{\circ} 55^{\prime} \mathrm{E}\right)$, Białystok prov. Sample coll and subm by M Prószczyński, Quaternary Research Comm, Warsaw.

\section{Brzesé Kujawski series}

Three samples from Kuczyna and Brześć Kujawski $\left(52^{\circ} 36^{\prime} \mathrm{N}, 18^{\circ}\right.$ $53^{\prime}$ E), Włocławek prov. Material dates from Linear Pottery culture. Samples dated to establish evolution of Kuyavian Funnel Beaker culture. Coll and subm by R Grygiel.

\section{LOD-93. Kuczyna}

Charcoal from clay pit, depth 0.8 to $1 \mathrm{~m}$.

LOD-110. Brzesé Kujawski

$5160 \pm 180$

Charcoal, Site 3, Pit 773, depth 1.2m.

LOD-127. Brzesé Kujawski

$5850 \pm 170$

Charcoal from burn layer of hearth, depth 0.7 to $0.9 \mathrm{~m}$.

LOD-107. Mosty Village

$11,290 \pm 280$

Charcoal from Mosty Village $\left(50^{\circ} 47^{\prime} \mathrm{N}, 20^{\circ} 25^{\prime} \mathrm{E}\right)$, Kielce prov, from hearth, depth 0.3 to $0.35 \mathrm{~m}$. Dated to assign dwelling feature of hut type to definite culture. Coll and subm by K Cyrek, Archaeol and Ethnog Mus, Lódź.

LOD-111. Olbrachcice

$12,680 \pm 230$

Charcoal from Olbrachcice $\left(51^{\circ} 40^{\prime} \mathrm{N}, 16^{\circ} 30^{\prime} \mathrm{E}\right)$, Leszno prov. Sample was scattered within pressed wood at depth 0.4 to $0.6 \mathrm{~m}$. Dated to establish chronology of Hamburg culture in Poland. Dates from NW Europe contradict each other. Coll and subm by M Burdukiewicz, Inst Archaeol, Warsaw Univ.

\section{Winnica series}

Three charcoal samples from Winnica $\left(50^{\circ} 29^{\prime} \mathrm{N}, 21^{\circ} 17^{\prime} \mathrm{E}\right)$. Tar- 
nobrzeg prov, from box construction of rampart. Dated to establish chronology of 1st stage of earthworks in Winnica. Coll and subm by $\mathrm{E}$ Tworowska, Inst Archaeol, Warsaw Univ.

LOD-124. Winnica 1

$920 \pm 90$

Charcoal, depth 2.6 to $2.65 \mathrm{~m}$.

LOD-125. Winnica 2

$870 \pm 90$

Charcoal, depth 2.55 to $2.6 \mathrm{~m}$.

LOD-126. Winnica 3

$800 \pm 90$

Charcoal, depth 2.5 to $2.58 \mathrm{~m}$.

\section{Stobnica Trzymorgi series}

Stobnica Trzymorgi $\left(51^{\circ} 25^{\prime} \mathrm{N}, 19^{\circ} 55^{\prime} \mathrm{E}\right)$, Piotrków Trybunalski prov, is on left bank of Pilica $\mathrm{R}$, in region of greatest loop of middle course of river. Site is on point of dune elev, on left bank of Stobniczanka $\mathrm{R}$ near its juncture with Pilica $\mathrm{R}$. Site is multicomponent unit consisting of Neolithic settlements and traces of habitation from Bronze Age III, Hallstatt period, Late La Tène period, Roman period, Early Middle Ages. Settlement of Venedian culture, which dates from Late La Tène, is richest-60 hearths and 5 traces of post-supported dwellings were discovered. Excavation was conducted by $\mathrm{H}$ Wiklak who coll and subm all samples described below.

LOD-128. Stobnica 1

$2160 \pm 110$

Charcoal, Hearth 12, depth 0.4 to $0.6 \mathrm{~m}$.

LOD-129. Stobnica 2

$2130 \pm 110$

Charcoal, Hearth 16, depth 0.4 to $0.6 \mathrm{~m}$.

LOD-130. Stobnica 3

$2160 \pm 100$

Charcoal, Hearth 11, depth 0.4 to $0.6 \mathrm{~m}$.

LOD-131. Stobnica 4

$2190 \pm 100$

Charcoal, Hearth 10, depth 0.4 to $0.6 \mathrm{~m}$.

LOD-132. Stobnica 5

$2110 \pm 110$

Charcoal, Hearth 18, depth 0.4 to $0.6 \mathrm{~m}$.

LOD-133. Stobnica 6

$2240 \pm 100$

Charcoal, Hearth 15, depth 0.4 to $0.6 \mathrm{~m}$.

LOD-134. Stobnica 7

$2160 \pm 100$

Charcoal, Hearth 20, depth 0.4 to $0.6 \mathrm{~m}$.

LOD-135. Stobnica 8

$2190 \pm 110$

Charcoal, Hearth 46 , depth 0.4 to $0.6 \mathrm{~m}$.

LOD-136. Stobnica 9

$2070 \pm 110$

Charcoal, Hearth 59, depth 0.4 to $0.6 \mathrm{~m}$. 
LOD-137. Stobnica 10

$2150 \pm 110$

Charcoal underlying stone pavement which composed bottom of hearth no. 2, depth 0.4 to $0.6 \mathrm{~m}$.

LOD-138. Stobnica 11

$2110 \pm 100$

Charcoal, Hearth 2, depth 0.4 to $0.6 \mathrm{~m}$.

\section{Kochlew series}

Site is on high sandy terrace of upper course of Warta $\mathrm{R}\left(51^{\circ} 12^{\prime} \mathrm{N}\right.$, $\left.18^{\circ} 48^{\prime} \mathrm{E}\right)$, Sieradz prov. This is well studied Late Palaeolithic camp with highly developed flint production. Near flint workshop were found hearths, domestic pits, and two features of hut dwelling. Samples coll and subm by K Cyrek. Excavation was conducted from 1975-1979.

LOD-141. Kochlew 1

$140 \pm 90$

Charcoal, depth $0.5 \mathrm{~m}$.

LOD-142. Kochlew 2

$10,320 \pm 220$

Humus with charcoal, depth 0.8 to $1 \mathrm{~m}$.

LOD-143. Kochlew 3

$10,260 \pm 210$

Humus sand with charcoal, depth 0.9 to $1 \mathrm{~m}$.

LOD-144. Kochlew 4

$11,180 \pm 220$

Peat, depth $0.9 \mathrm{~m}$.

\section{Lykowe series}

This multicomponent site is on high, sandy terrace of upper course of Warta R (51 $\left.11^{\prime} \mathrm{N}, 18^{\circ} 47^{\prime} \mathrm{E}\right)$, Sieradz prov. Oldest complex of site dates from Late Palaeolithic period, rich in lithic workshop inventory with diagnostic leaf-shaped points of tundra cultures. Mesolithic parts of wooden foot-bridge and fragments of burials are present among dating samples. Coll and subm by M Cyrek and K Cyrek.

LOD-145. Lykowe 3

$5430 \pm 190$

Charcoal with humus, depth $0.9 \mathrm{~m}$.

LOD-146. Lykowe 2

$5380 \pm 180$

Charcoal, depth 0.7 to $0.9 \mathrm{~m}$.

LOD-14.7. Lykowe 9

$4630 \pm 160$

Sandy peat, depth $0.7 \mathrm{~m}$.

LOD-148. Lykowe 8

$10,380 \pm 220$

Oozy sand with humus fragments, depth $1.8 \mathrm{~m}$.

LOD-149. Lykowe 7

$9150 \pm 210$

Sandy peat, depth $1.1 \mathrm{~m}$.

LOD-150. Lykowe 6

$8070 \pm 180$

Sandy peat, depth $1 \mathrm{~m}$. 
LOD-151. Lykowe 1

Charcoal with humus, depth $0.8 \mathrm{~m}$.

GEOI.OGIC SAMPLES

\section{Chrapanów series}

Humus from Chrapanów (50 $\left.50^{\circ} 50^{\prime} \mathrm{N}, 21^{\circ} 43^{\prime} \mathrm{E}\right)$, Tarnobrzeg prov. Samples coll from fossil soil in lower level of ditch, fossil soil. Samples were dated to determine age of erosion fossil forms as well as age of sedimentation in Cizyzówka $\mathrm{R}$ valley, effluent of Vistula $\mathrm{R}$ near Zawichost. Samples coll and subm by D Kosmowska-Suffczyńska, Inst Geog, Warsaw Univ.

LOD-17. Chrapanów site; Level A

$5 \mathbf{1 4 0} \pm 120$

Depth 5 to $5.25 \mathrm{~m}$.

LOD-18. Chrapanów site; Level B

$11,000 \pm 380$

Depth 5.25 to $5.5 \mathrm{~m}$.

LOD-21. Strbskie Pleso, Czechoslovakia

$\mathbf{7 0 7 0} \pm \mathbf{2 4 0}$

Lacustrine, non-carbonate organic sediment from Strbskie Pleso lake, Slovak Tatras, $\left(49^{\circ} 20^{\prime} \mathrm{N}, 20^{\circ} 02^{\prime} \mathrm{E}\right)$ at depth $15 \mathrm{~m}$. Sample coll by K Więckowski with metal sampling probe of his own design from sediment bed at 1.9 to $2.4 \mathrm{~m}$ below bottom of lake. Dated to determine age of Tatras Mt lakes. Sample subm by J Kondracki, Inst Geog, Warsaw Univ.

\section{Lomzyca series}

Samples coll during borings in flood plain of Lomzyczka $\mathrm{R}$ in Lomzyca $\left(53^{\circ} 10^{\prime} \mathrm{N}, 22^{\circ} 02^{\prime} \mathrm{E}\right)$. These dates should solve problem of lacustrine sediment stratigraphy of "Lomzyca" water reservoir and its geochronology. Samples coll and subm by K Straszewska, Dept Geol Sci, Polish Acad Sci, Warsaw.

LOD-22. Lomzyca 2

Slightly decomposed and pressed peat coll from wall of drainage ditch at depth $2.4 \mathrm{~m}$.

LOD-23. Lomzyca 1

$11,790 \pm 290$

Brown decomposed peat with small admixture of sand coll from $\mathrm{S}$ side of viaduct at depth 3.3 to $3.4 \mathrm{~m}$.

LOD-24. Lomzyca 3

$>\mathbf{2 8 , 0 0 0}$

Dark gray, sandy silt from foundation trench of factory building at 4.6 to $4.65 \mathrm{~m}$ depth. Sample overlay sediments from which LOD-22 and -23 were coll. Comment: this series probably extracted from sediments of cold period which preceded max extension of continental glacier that covered Baltic Sea (Borówka-Dłuzakowa, 1957; Straszewska, 1968). 
LOD-119. Lomzyca 5

$10,900 \pm 230$

Decomposed peat with loam from site on grounds of "Korgaz" Gas Communal Bottling Plant, Lomza. Sample coll with borer from depth 3.3 to $3.7 \mathrm{~m}$.

LOD-139. Lomzyea 7

Gyttja from well boring at depth 5.7 to $7.8 \mathrm{~m}$, from "Korgaz" Gas Communal Bottling Plant, Lomza.

LOD-140. Lomzyea 6

$$
11,030 \pm 380
$$

Fossil soil with slight amount of carbon $(2.8 \%)$. Sample coll with borer on grounds of lacustrine reservoir from depth 3.3 to $3.6 \mathrm{~m}$.

\section{Skorupy series}

Peat from Skorupy village $\left(52^{\circ} 03^{\prime} \mathrm{N}, 21^{\circ} 26^{\prime} \mathrm{E}\right)$, Warsaw prov. Samples removed with borer from top part of organic drift series. Samples coll to study character of fossil and relict soils created from rocks of different origins. Samples coll and subm by D Baraniecka, Inst Sci Soil, Acad Agric, Warsaw.

LOD-25. Skorupy 1

$>28,000$

Peat from depth 6.9 to $7.7 \mathrm{~m}$.

LOD-26. Skorupy 2

$>\mathbf{2 8 , 0 0 0}$

Peat from depth 6.9 to $7.7 \mathrm{~m}$.

\section{Niewiadowo series}

Samples from Niewiadów village $\left(53^{\circ} 08^{\prime} \mathrm{N}, 22^{\circ} 11^{\prime} \mathrm{E}\right)$ near Lomza. First sample was within range of water-level oscillation of Narew $R$ at depth 2 to $2.3 \mathrm{~m}$. Age of samples should contribute to dating of Narew $\mathbf{R}$ Quaternary series and determine upper age limit for formation of fossil soil. Coll and subm by K Straszewska.

LOD-27. Niewiadowo 1

$1420 \pm 130$

Wood from oak trunk underlying sediment of Quaternary formation of Narew R, depth 2 to $2.3 \mathrm{~m}$.

LOD-99. Niewiadowo 2

$1380 \pm 110$

Charcoal in fossil soil from dune, depth 1.5 to $2 \mathrm{~m}$.

\section{Osuchy series}

Peat from Osuchy village $\left(50^{\circ} 29^{\prime} \mathrm{N}, 22^{\circ} 58^{\prime} \mathrm{E}\right)$, Zamość prov, from uncropped layer at terrace edge of Tanew $\mathrm{R}$ undercut by stream. Samples dated to determine age of terrace of Tanew $\mathrm{R}$. Coll and subm by $\mathrm{W}$ Laskowska-Wysoczyńska, Dept Sci, Polish Acad Sci, Warsaw.

LOD-28. Osuchy 418

$8900 \pm 220$

Peat, depth $1 \mathrm{~m}$. 
LOD-98. Osuchy 420

$9380 \pm 230$

Peat, depth $1.4 \mathrm{~m}$.

\section{Rosle series}

Peat and charcoal from Rośle $\left(52^{\circ} 08^{\prime} \mathrm{N}, 18^{\circ} 54^{\prime} \mathrm{E}\right)$, Konin prov coll from different parts of dune near Ner R. Dated to reconstruct evolution of dune formation, $i e$, paleogeography of Warsaw-Berlin ice-marginal valley near Uniejów. Strata from which samples were coll probably date from early Holocene (Krajewski, 1976) or Late Pleistocene. Coll and subm 1975 by K Krajewski, Inst Geog, Lódź Univ.

LOD-29. Rosle

$12,420 \pm 280$

Peat from top stratum at base of dune, depth $4 \mathrm{~m}$.

LOD-37. Rosle 7

$12,140 \pm 290$

Peat from stratum of base of dune, depth $4 \mathrm{~m}$.

LOD-40. Rosle 5

$11,920 \pm 240$

Charcoal with single coal from stratum of fossil soil, depth $2.7 \mathrm{~m}$.

LOD-41. Podgórze

$3740 \pm 150$

Charcoal from stratum of fossil soil, with single coals, depth $2.5 \mathrm{~m}$.

\section{Cieciwa series}

Samples from Cięciwa $\left(52^{\circ} 15^{\prime} \mathrm{N}, 21^{\circ} 28^{\prime} \mathrm{E}\right)$ and Wiązowna $\left(52^{\circ} 10^{\prime}\right.$ $\mathrm{N}, 17^{\circ} 20^{\prime} \mathrm{E}$ ), Warsaw prov coll from sand quarry. Dated to determine stratigraphic division of dunes and fossil soil, as element of geog environment near Warsaw. Coll and subm by $\mathrm{K}$ Konecka-Betley, Inst Sci Soil, Acad Agric, Warsaw.

LOD-30. Cieciwa 3/6

$11,150 \pm 300$

Charcoal from soil layer, depth $6 \mathrm{~m}$.

LOD-31. Cieciwa $3 / 2$

$6150 \pm 270$

Peat from top layer of fossil soil, depth $2 \mathrm{~m}$.

LOD-32. Wiazowna

$10,340 \pm 450$

Mineral soil including humus fragments, depth $18 \mathrm{~m}$.

LOD-47. Cieciwa

$7150 \pm 350$

Mineral soil including humus fragments, depth $2 \mathrm{~m}$.

LOD-33. Kunów

$3410 \pm 160$

Charcoal from Kunów $\left(50^{\circ} 57^{\prime} \mathrm{N}, 21^{\circ} 16^{\prime} \mathrm{E}\right)$, Kielce prov, scattered in loess. Sample coll from natural outcrop in valley; dated to determine age of fossil soils and evolution of soil-forming process during Holocene (Jersak, 1965), depth 4.35 to $5.2 \mathrm{~m}$. Coll and subm by J Jersak, Inst Geog, Lódź Univ.

LOD-34. Nietulisko Małe

$8420 \pm 170$

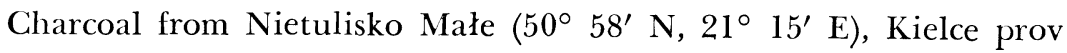


from layer of bones and coals deposited on bottom of partly buried suffosio tunnel. Research site was set up at side branch of large gorge, $+218 \mathrm{~m}$, ca $38 \mathrm{~m}$ above bottom of Swiślina Valley. Coll and subm by $\mathrm{Z}$ Snieszko, Inst Geog, Lódź Univ.

\section{LOD-35. Odonów I}

$6020 \pm 250$

Humus from Odonów $\left(50^{\circ} 15^{\prime} \mathrm{N}, 20^{\circ} 30^{\prime} \mathrm{E}\right)$, Kielce prov from arable level formed on loess, depth $2 \mathrm{~m}$. Coll and subm by $\mathrm{Z}$ Snieszko.

\section{Szynkielów series}

Three samples from Szynkielów site $\left(51^{\circ} 22^{\prime} \mathrm{N}, 18^{\circ} 45^{\prime} \mathrm{E}\right)$, two samples from Kamion site $\left(52^{\circ} 21^{\prime} \mathrm{N}, 20^{\circ} 11^{\prime} \mathrm{E}\right)$ and one from Młodzieszynek site $\left(52^{\circ} 21^{\prime} \mathrm{N}, 20^{\circ} 10^{\prime} \mathrm{E}\right)$, Skierniewice prov. Dated to determine age of fossil soil as part of study of evolution of soil cover in Late Pleistocene and Holocene (Manikowska, 1977; Wasylikowa, 1976). Samples coll from sand pit of dune. Coll and subm by B Manikowska, Inst Geog, Lódź Univ.

LOD-36. Szynkielów 1

$4720 \pm 140$ $0.5 \mathrm{~m}$.

Charcoal from humus level of fossil podzol in dune $0.1 \mathrm{~m}$ thick, depth

\section{LOD-43. Kamion 1}

$12,230 \pm 260$

Humus scattered in sand with admixture of dust from initial level of humus of fossil soil in dune, depth 1 to $1.5 \mathrm{~m}$.

LOD-44. Szynkielów 2

$5310 \pm 150$

Humus from sandy Quaternary formation at level of fossil podzol, depth $0.75 \mathrm{~m}$.

LOD-83. Szynkielów 3

$8790 \pm 190$

Charcoal, depth $2 \mathrm{~m}$.

LOD-84. Młodzieszynek 1

$10,830 \pm 250$

Charcoal, depth 1.2 to $1.7 \mathrm{~m}$.

LOD-85. Kamion 2

$14,590 \pm 270$

Humus scattered in argillo-arenaceous sediment, depth $2.5 \mathrm{~m}$.

\section{Skarzysko series}

Fossil soil and peat from Skarzysko Kamienna $\left(51^{\circ} 07^{\prime} \mathrm{N}, 20^{\circ} 50^{\prime} \mathrm{E}\right)$ and Brody Iłzeckie ( $\left.51^{\circ} 02^{\prime} \mathrm{N}, 21^{\circ} 05^{\prime} \mathrm{E}\right)$, Kielce prov. Samples come from continuous soil level, coll by J Bartosik, Inst Geog, Paedagog Coll, Kielce; subm by Z Ksiązak, Inst Geog, Paedagog Coll, Kielce.

LOD-77. Skarzysko Kamienna

$>28,000$

Black peat with organic fragments, depth ca $8 \mathrm{~m}$.

LOD-78. Brody Iłzeckie

$11,080 \pm 280$

Fossil soil, peat, depth ca $2 \mathrm{~m}$. 
LOD-86. Kalinko

Humus scattered in oozy and sandy material from Kalinko village $\left(51^{\circ} 38^{\prime} \mathrm{N}, 19^{\circ} 33^{\prime} \mathrm{E}\right)$, Lódź prov. Sample from irrigation ditch, Pilica R, Lódź, depth 1.3 to $1.5 \mathrm{~m}$. Test sample contained min amount of organic compounds. Dated to study Würmian stratigraphy and palaeogeography of Lódź region. Coll and subm by B Manikowska.

LOD-87. Gaski 1

$10,450 \pm 260$

Peat underlying dune sands of Baltic beach, depth 2.5m, from Gaski village $\left(54^{\circ} 15^{\prime} \mathrm{N}, 15^{\circ} 34^{\prime} \mathrm{E}\right)$, Koszalin prov. Dated to study evolution of shoreline and formation of coastal dune (Narsz, 1966). Coll and subm by K Krajewski.

\section{Kampinos Nart series}

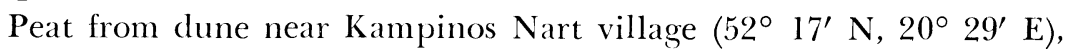
Warsaw prov. Dated to explain formation of dunes in Kampinos Natl park. Coll and subm by K Konecka-Betley.

LOD-91. Kampinos Nart 1

$$
5400 \pm 250
$$

Peat, depth 1.55 to $1.7 \mathrm{~m}$.

LOD-94. Kampinos Nart 2

$7110 \pm 320$

Peat, depth 2.3 to $2.8 \mathrm{~m}$.

LOD-103. Kampinos Nart 3

$6850 \pm 200$

Peat, depth 1.55 to $1.7 \mathrm{~m}$.

LOD-104. Kampinos Nart 4

$7300 \pm 230$

Peat, depth 2.3 to $2.8 \mathrm{~m}$.

LOD-105. Kampinos Nart 5

$5650 \pm 210$

Peat, depth 1.55 to $1.7 \mathrm{~m}$.

LOD-106. Kampinos Nart 6

$5200 \pm 180$

Peat, depth 1.55 to $1.7 \mathrm{~m}$.

\section{Zerniki series}

Samples from Zerniki $\left(50^{\circ} 46^{\prime} \mathrm{N}, 20^{\circ} 24^{\prime} \mathrm{E}\right)$, Kielce prov. Dated to study evolution of valley bottom of Nida $\mathrm{R}$ during Holocene. Coll and subm by $\mathrm{Z}$ Snieszko.

\section{LOD-95. Zerniki 1}

$1930 \pm 190$

Wood from trunks in so-called "black oaks level", depth $2 \mathrm{~m}$ from basal sediment of Holocene terrace.

LOD.96. Zerniki 2

$2200 \pm 200$

Charcoal within fossil soil, depth $1 \mathrm{~m}$.

LOD-108. Osówka Stara

$5200 \pm 190$

Fossil soil with charcoal from Osówka Stara village $\left(50^{\circ} 37^{\prime} \mathrm{N}, 21^{\circ}\right.$ $00^{\prime} \mathrm{E}$ ), Kielce prov, depth $2.6 \mathrm{~m}$. Coll and subm by K Ksiązak. 
Lack series

Samples from Ląck $\left(53^{\circ} 32^{\prime} \mathrm{N}, 19^{\circ} 36^{\prime} \mathrm{E}\right)$, Płock prov. Gyttja coll from lake basin, in run-off water discharge basin between oozes. Coll and subm by K Konecka-Betley.

LOD-109. Lack 1

$10,260 \pm 260$

Gyttja, depth 6.52 to $6.99 \mathrm{~m}$.

LOD-123. Lack 2

$10,440 \pm 260$

Gyttja, depth 6.45 to $6.6 \mathrm{~m}$.

\section{Bełchatów series}

Samples from Rogowiec and Bełchatów $\left(51^{\circ} 14^{\prime} \mathrm{N}, 19^{\circ} 23^{\prime} \mathrm{E}\right)$, Piotrków Trybunalski prov, from open mine in Bełchatów or from directly adjoining fields. Dated to elaborate on cross-section of Würmian sediments. Coll and subm by J Goździk, Inst Geog, Lódź Univ.

LOD-115. Rogowiec

$13,400 \pm \mathbf{5 5 0}$

Charcoal from fossil soil in cut near mine, depth $1.2 \mathrm{~m}$.

LOD-116. Bełchatów-"Piaski"

$14,350 \pm 580$

Fir cone and other vegetal remains coll from top layer of brook sediment and from bottom side of silty sediment in cross-section of mine, depth $2.5 \mathrm{~m}$.

LOD-117. Bełchatów-“Piaski"”

$31,000 \pm 900$

Ooze with organic material (humus) from organic ooze underlying Würmian sediment of brook in cross-section of mine, depth $20 \mathrm{~m}$.

LOD-118. Bełchatów-"Piaski"

$\mathbf{2 5 , 2 0 0} \pm \mathbf{7 4 0}$

Sample from ooze formation with admixture of organic material underlying sediments of brook, depth $18 \mathrm{~m}$.

\section{Inowłódz series}

Samples from central part of ancient Pilica riverbed meander Inowłódz $\left(51^{\circ} 31^{\prime} \mathrm{N}, 20^{\circ} 13^{\prime} \mathrm{E}\right)$, Piotrków Trybunalski prov. Samples were bored manually, dated to study transitions of horizontal river bed of Pilica R from Middle ages to 19 th century. All samples coll by W Balinski, subm by J Augustyniak, The Centre for Research in Documentation of Monuments, Lódź.

LOD-120. Inowłódz I/1 $720 \pm 90$

Peaty silt, depth 1.4 to $1.6 \mathrm{~m}$.

LOD-121. Inowłódz I/2

$560 \pm 80$

Peaty silt, depth 1 to $1.3 \mathrm{~m}$.

LOD-122. Inowłódz I/4

$760 \pm 90$

Peaty silt, depth 1.4 to $1.6 \mathrm{~m}$. 
LOD-152. Inowłódz II/5

$490 \pm 80$

Ooze with organic fragments, depth 1.2 to $1.6 \mathrm{~m}$.

LOD-153. Inowłódz II/4

$620 \pm 90$

Peaty silt, depth $1 \mathrm{~m}$.

LOD-154. Inowłódz II/3

Modern

Ooze with organic fragments, depth $0.8 \mathrm{~m}$.

LOD-155. Inowłódz II/2

$490 \pm 80$

Silt with organic fragments, depth 1.2 to $1.3 \mathrm{~m}$.

LOD-156. Inowlódz II/1

$610 \pm 90$

Peat, depth 1.3 to $1.4 \mathrm{~m}$.

R FFERENCES

Barker, H, Burleigh, R, and Meeks, N, 1969, New method for the combustion of samples for radiocarbon dating: Nature, $v 221$, p 49-50.

Bem, H, Gebicka, E, Gebicki, J, and Kanwiszer, A, 1978, The $\mathrm{CO}_{2}$ preparation from samples of low carbon concentration for methane synthesis in radiocarbon dating: Radiochem Radioanal Letters, v 35, no. 3, p 133-138.

Borówka-Dł́uzakowa, Z, 1957, Interglacjały Suwalszczyzny i terenów sasiednich: Acta Geol Pol, v 7, no. 4.

Fairhall, A W, Schell, W R, and Takashima, Y, 1961, Apparatus for methane synthesis for radiocarbon dating: Rev Sci Instruments, $v$ 32, p 323-325.

Gabałówna, L, 1970, Pit "A" with charred wheat from TRB habitation Site 1 at Radziejów Kujawski: Prace Materiały Muz Archeol Etnograf Lodzi, v 17, p 157-163.

Grygiel, R, 1977, Settlements of the Linear pottery (Danubian) culture at Brześc Kujawski near Włocławek: Prace Materiały Muz Archeol Etnograf Lodzi, v 23, p 5-111.

Jersak, J, 1965, Stratygrafia i geneza lessów okolic Kunowa: Acta Geog Lodziensia, v 20.

Krajewski, K, 1976, Póznoplejstoceńskie i holoceńskie procesy wydmotwórcze w pradolinie Warszawsko-Berlińskiej w widłach Warty i Neru: Acta Geog Lodziensia, v 39.

Libby, W F, 1952, Radiocarbon dating: Chicago, Univ Chicago Press, 124 p.

Manikowska, B, 1977, The development of soil cover: Quaest Geog, v 4.

Marsz, A, 1966, Geneza wydm łebskich w świetle współczesnych procesów brzegowych: Prace Kom Geog-Geol Pozn Tow Przyjaciół Nauk, v 4, no. 4.

Straszewska, K, 1968, Stratygrafia Plejstocenu i paleogeomorfologia rejonu dolnego Bugu: Studies Geog Poland, v 23.

Switsur, V R, 1974, A new sample combustion bomb for radiocarbon dating: Appl Radiation and Isotopes Jour, v 25, p 113-117.

Switsur, V R, Hall, M A, and West, R G, 1970, University of Cambridge natural radiocarbon measurements IX: Radiocarbon, v 12, p 590-598.

Wasylikowa, K, 1976, Roślinność i klimat Póznego Glacjału: Perygl Biul, v 13. 